\title{
Chemical Composition and Anti-scabies Activity of Essential Oil of Elettaria Cardamomum Maton. Leaves
}

\author{
Bharat Sharma $^{1}$, Neeru Vasudeva ${ }^{1 \star}$, Sunil Sharma ${ }^{1}$ \\ 1 Department of Pharmaceutical Sciences, Guru Jambheshwar University of Science and Technology, Hisar 125001, \\ Haryana, India
}

\begin{abstract}
The objective of this study was to investigate the chemical constituents of essential oil of Elettaria cardamomum leaves and assess its anti-scabies potential.

Essential oil obtained by hydrodistillation of fresh leaves of E. cardamomum, subjected to gas chromatography, gas chromatography-mass spectrometry for identification and quantification of components. Anti-scabies potential of essential oil of $E$. cardamomum leaves against $S$. scabiei was investigated by contact bioassay method.
\end{abstract}

GC and GC-MS analysis results revealed the presence of 44 compounds, representing $96.42 \%$ of the oil. The volatile components in leaves of E. cardamomum were made up of largely of oxygenated monoterpenes including terpinen-4-ol, eucalyptol, p-cymene, trans-phytol and cis-sabinene. The anti-scabies study revealed that $10 \%$ E. cardamomum oil showed $100 \%$ mortality within 60 min.

This study demonstrated the potential of E. cardamomum leaves essential oil as a scabicidal agent, therefore can be used as an alternative for the cure and effective control of S. scabiei.

Keywords: Elettaria cardamomum, Essential oil, GC, GC-MS, Anti-scabies

\section{INTRODUCTION}

Sarcoptes scabiei var hominis "itch mite", family Sarcoptidae, causes a contagious pruritic skin infestation in animals and humans (Scabies). According to $\mathrm{WHO}$, it affects more than 130 million people ubiquitously at any time and prevalence varies from 0.35 to $46 \%{ }^{1}$. In tropical regions, it is epidemiologi-

\footnotetext{
*Corresponding Author: Neeru Vasudeva, e-mail: neeruvasudeva@gmail.com Bharat Sharma ORCID Number: 0000-0002-8498-3950 Neeru Vasudeva ORCID Number: 0000-0001-5656-6562 Sunil Sharma ORCID Number: 0000-0002-0768-4367 (Received 08 October 2019, accepted 05 December 2019)
} 
cally evidenced that, scabies generally cause pyoderma and eventually serious illness due to invasion by opportunistic bacteria. Such infections can lead to cellulitis, bacteraemia and sepsis, kidney and heart disease that will increase health burden in resource-poor communities ${ }^{2}$. Due to suboptimal efficacy of few available therapies, the treatment of Sarcoptes scabiei infection is getting hindered in human being ${ }^{1}$.

Elettaria cardamomum Maton., cardamom, universally known as "queen of spices", is dried fruit of a herbaceous perennial shrub belonging to the family Zingiberaceae. Cardamom is endemic to South Asia but is mercantily cultivated in Southern India on the shady slopes of Ghats (mostly in Tamilnadu, Kerala and Karnataka), Nepal, Sri Lanka, Guatemala, Thailand, Mexico, Tanzania and Central America ${ }^{3}$. In Indian Ayurvedic system of medicine, it is used for alleviating skin and urinary problems ${ }^{4}$. Cardamom is commonly used as antiseptic, carminative, expectorant, diuretic, breath freshener, desiccant, stomachic, anti-emetic and as an aphrodisiac ${ }^{5-7}$. E. cardamomum have been reported to have various biological potential such as antimicrobial ${ }^{8-9}$, anti-inflammatory ${ }^{10}$, bronchodilator ${ }^{11}$, blood pressure lowering ${ }^{12}$, gastroprotective ${ }^{13-17}$, sedative and anticonvulsant ${ }^{18}$, anticancer, antihypertensive, antioxidant and anti platelet aggregation ${ }^{19}$.

Due to biological and medicinal importance, the present study is carried out to analyse and characterise the bioactive constituents present in essential oil of leaves of $E$. cardamomum by gas chromatography (GC) and gas chromatography-mass spectrometry (GC-MS) technique and further to assess the in vitro anti-scabies potential of essential oil against Sarcoptes scabiei.

\section{METHODOLOGY}

\section{Plant material}

The leaves of E. cardamomum were collected from Botanical Garden, Mallah, Morni Hills, India. The leaf samples were identified and authenticated by Dr. Satish Kumar, Taxonomist at Department of Botany, Government College of Girls, Bhodia Khera, Fatehabad, Haryana. A voucher specimen (GJUPCOG160015 I) was preserved in the Herbarium of Department of Pharmaceutical sciences, Guru Jambheshwar University of Science and Technology, Hisar, Haryana, India. The fresh leaves (100g) of were distilled for $6 \mathrm{~h}$ to obtain oil by hydro-distillation method using Clevenger's apparatus. The oil was collected over anhydrous sodium sulphate in a glass vial to obtain pure oil, without any traces of moisture and stored at $40^{\circ} \mathrm{C}$ until used ${ }^{20}$. 


\section{Analysis of the essential oil}

The gas chromatographic (GC) analysis of essential oil was carried out using a Shimadzu GC-2010 Gas chromatography equipped with flame ionization detector using Rtx 5 MS capillary column (RESTEK Company: crossbond 5\% diphenyl/ 95\% dimethyl polysiloxane) having dimensions 30m (Length) $\mathrm{x}$ $0.25 \mathrm{~mm}$ (diameter) x $0.25 \mu \mathrm{m}$ df (film thickness). The sample (0.2 $\mu \mathrm{L}$ ) was injected into the column with a split ratio of 1:100. The analytical conditions were: carrier gas $(\mathrm{N} 1.21 \mathrm{~mL} / \mathrm{min}, 69.0 \mathrm{kPa})$, injector temperature $260^{\circ} \mathrm{C}$, detector (FID) temperature $280^{\circ} \mathrm{C}$, oven temperature $50^{\circ} \mathrm{C}$ ( 2 min hold) to 280 ${ }^{\circ} \mathrm{C}$ (9 min hold) at $3{ }^{\circ} \mathrm{C} / \mathrm{min}$. The retention indices (RIs) were in relation to homologous series of n-alkane $\left(\mathrm{C}_{9}\right.$ to $\mathrm{C}_{33}$ ) on the Rtx 5 MS capillary column under the same chromatographic condition.

GC-MS analysis was performed using GCMS-QP2010 Plus, Shimadzu, system equipped with mass selective detector, having ion source temperature $230{ }^{\circ} \mathrm{C}$, Interface Temp. $-270{ }^{\circ} \mathrm{C}$, Solvent Cut Time -2.50 min threshold of $1000 \mathrm{v}$ and mass range was 40-650 m/z, Rtx 5 MS capillary column and aforementioned chromatographic conditions, with He used as a carrier gas.

Compounds were identified using two methods, one of the methods was based on comparison of mass spectra with the data in NIST or Wiley library. The other one was by comparison of their retention indices (RIs) with those which reported in literature for Rtx 5 MS capillary column.

\section{In vitro anti-scabies activity}

\section{Collection of mites}

The Sarcoptes scabiei mites were isolated from scabes and ear cerumen of infested legs and ears of rabbits under clinical examination by Dr. Snahil Gupta, Assistant Professor, Department of Veterinarian Parasitology, Lala Lajpat Rai University of Veterinary and Animal Sciences, Hisar, Haryana. The morphologically characterized mites were placed in petri dishes and motile adult mites were collected for testing.

\section{Contact bioassay}

The essential oil was diluted with paraffin oil to get concentrations of $1 \%, 5 \%$ and $10 \%$. Ten mites were placed in each petri dish and then in petri dishes $1 \mathrm{~mL}$ of diluted solution was added in direct contact with adult mites. Three replicates were performed for each concentration of oil. Permethrin $5 \%$ was used as a positive control and liquid paraffin was used as a negative control. The mites were inspected under stereomicroscope (Olympus) 20, 40, 60, 80 min after 
inoculation. Mites were considered dead when no movement was seen even after touching it with needle and no gut movement was observed over 2 min ${ }^{1}$.

\section{Statistical analysis}

\% Mortality was calculated and expressed as mean \pm SEM and significance of difference was determined by two-way ANOVA test using Graph Pad Prism.

\section{RESULTS AND DISCUSSION}

\section{Essential oil analysis}

Hydrodistillation of leaves of E. cardamomum generated yellowish green liquid with a yield of $2 \%$. The GC and GC-MS analysis of essential oil of leaves of $E$. cardamomum allowed the identification and quantification of $44 \mathrm{com}-$ ponents which accounts for $96.42 \%$ of the total oil, as presented in Figure 1. The identified components of the essential oil of E. cardamomum as well as their percentage area and retention indices are reported in Table 1 . The oxygenated monoterpenes (65.62\%) dominated in essential oil, with terpinen-4-ol (32.99\%), eucalyptol (19.82\%), p-cymene (10.17\%), trans-phytol (5.26\%), cis-sabinene (2.53\%), linalool (2.41\%), as the most abundant constituents, followed by oxygenated sesquiterpenes (9.45\%) with caryophyllene oxide (6.59\%), $\beta$-eudesmol (0.99\%), trans-nerodilol (0.59\%). Sesquiterpenes hydrocarbons (6.04\%) slightly prevailed over monoterpenes hydrocarbons (4.30\%). The monoterpenes hydrocarbons were mainly represented by $\beta$-pinene (1.54\%), $\beta$-ocimene (o.85\%), $\alpha$-thujene (o.75\%), $\alpha$-pinene (0.53\%). $\beta$-Farnesene (3.45\%) was the major constituent among sesquiterpene hydrocarbons in essential oil of E. cardamomum leaves. The findings obtained were compared with those reported earlier on E. cardamomum seeds, fruits or seed coat essential oil analysed by GC-MS. 


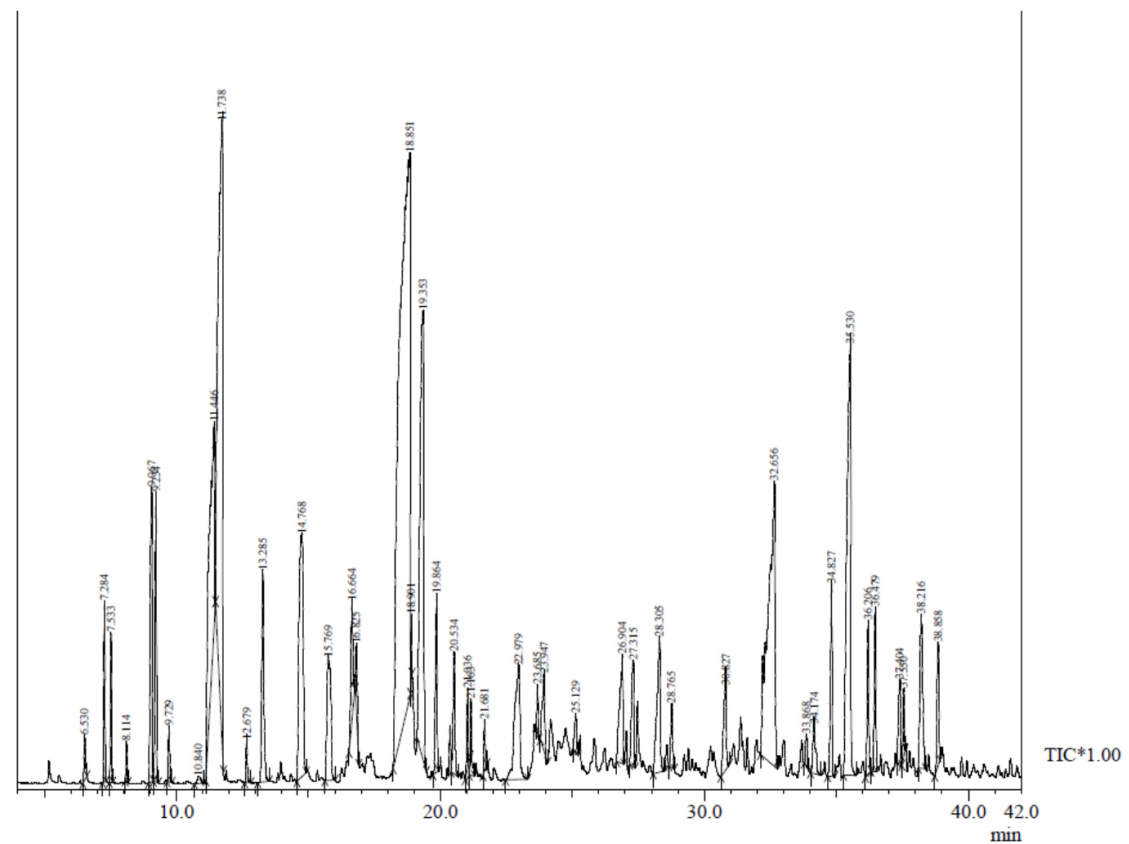

Figure 1. GC-MS chromatogram for essential oil of Elettaria cardamomum leaves 
Table 1.Volatile components in essential oil of leaves of Elettaria cardamomum

\begin{tabular}{|c|c|c|c|c|c|}
\hline Peak No. & Name & Area $\%$ & $\begin{array}{l}\mathbf{R l}^{\mathbf{a}} \\
\text { (Lit.) }\end{array}$ & $\begin{array}{c}\mathbf{R l}^{\mathrm{b}} \\
\text { (Exp.) }\end{array}$ & R. Time \\
\hline 1 & Heptan-2-ol & 0.21 & 896 & 903 & 6.530 \\
\hline 2 & $\alpha$-Thujene & 0.76 & 928 & 928 & 7.284 \\
\hline 3 & $\alpha$-Pinene & 0.53 & 941 & 930 & 7.533 \\
\hline 4 & Camphene & 0.12 & 946 & 945 & 8.114 \\
\hline 5 & cis-Sabinene & 2.53 & 972 & 970 & 9.067 \\
\hline 6 & $\beta$-Pinene & 1.54 & 976 & 975 & 9.234 \\
\hline 7 & Myrcene & 0.22 & 993 & 988 & 9.729 \\
\hline 8 & $\delta$-3-Carene & 0.11 & 1011 & 1015 & 10.840 \\
\hline 9 & p-Cymene & 10.17 & 1025 & 1029 & 11.446 \\
\hline 10 & Eucalyptol & 19.83 & 1031 & 1035 & 11.738 \\
\hline 11 & $\gamma$-Terpinene & 0.19 & 1063 & 1057 & 12.679 \\
\hline 12 & $\beta$-Ocimene & 0.85 & 1050 & 1070 & 13.285 \\
\hline 13 & Linalool & 2.41 & 1102 & 1104 & 14.768 \\
\hline 14 & cis-Menth-2-en-1-ol & 0.91 & 1122 & 1126 & 15.769 \\
\hline 15 & Camphor & 0.34 & 1143 & 1145 & 16.664 \\
\hline 16 & Pinocarvone & 1.43 & 1146 & 1148 & 16.825 \\
\hline 17 & Borneol & 1.56 & 1165 & 1170 & 17.703 \\
\hline 18 & Terpinen-4-ol & 32.99 & 1177 & 1174 & 18.851 \\
\hline 19 & Cryptone & 0.76 & 1192 & 1189 & 18.901 \\
\hline 20 & $\alpha$-Terpineol & 2.37 & 1193 & 1203 & 19.353 \\
\hline 21 & trans-Piperitol & 0.61 & 1208 & 1214 & 19.864 \\
\hline 22 & Nerol & 0.55 & 1226 & 1229 & 20.534 \\
\hline 23 & Ascaridole & 0.22 & 1237 & 1240 & 21.036 \\
\hline 24 & 4-Phenyl-2-butanone & 0.21 & 1251 & 1243 & 21.163 \\
\hline 25 & trans-2-Decenal & 0.20 & 1265 & 1254 & 21.681 \\
\hline 26 & Bornyl acetate & 0.59 & 1286 & 1283 & 22.979 \\
\hline 27 & Carvenone & 0.29 & 1252 & 1298 & 23.685 \\
\hline 28 & Isoledene & 0.38 & 1377 & 1304 & 23.947 \\
\hline 29 & $\begin{array}{l}\text { cis-Methyl-cinna- } \\
\text { mate }\end{array}$ & 0.78 & 1380 & 1372 & 26.904 \\
\hline 30 & Methyl cinnamylate & 0.37 & 1394 & 1381 & 27.315 \\
\hline 31 & Caryophyllene & 0.86 & 1417 & 1415 & 28.765 \\
\hline 32 & $\alpha$-Bergamotene & 0.43 & 1433 & 1465 & 30.827 \\
\hline 33 & $\beta$-Farnesene & 3.45 & 1455 & 1510 & 32.656 \\
\hline 34 & $\beta$-Bisabolene & 0.16 & 1506 & 1540 & 33.868 \\
\hline
\end{tabular}




\begin{tabular}{rccccc}
\hline 35 & $\gamma$-Cadinene & 0.34 & 1513 & 1543 & 33.927 \\
\hline 36 & trans-Nerodilol & 0.59 & 1569 & 1548 & 34.174 \\
\hline 37 & $\begin{array}{c}\text { Caryophyllene ep- } \\
\text { oxide }\end{array}$ & 0.20 & 1580 & 1565 & 34.827 \\
\hline 38 & Caryophyllene oxide & 6.06 & 1582 & 1583 & 35.530 \\
\hline 39 & Carotol & 0.45 & 1587 & 1600 & 36.206 \\
\hline 40 & Humulene epoxide & 0.51 & 1594 & 1607 & 36.479 \\
\hline 41 & Caryophylladienol II & 0.27 & 1631 & 1632 & 37.404 \\
\hline 42 & $\beta$-Eudesmol & 0.99 & 1641 & 1636 & 37.550 \\
\hline 43 & Guaiyl acetate & 0.36 & 1712 & 1654 & 38.216 \\
\hline 44 & trans-Phytol & 5.26 & 2099 & 1988 & 38.858 \\
\hline
\end{tabular}

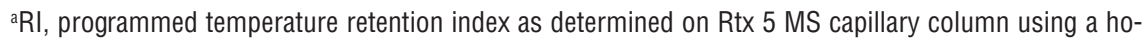
mologous series of $n$-alkanes $\left(\mathrm{C}_{9}\right.$ to $\left.\mathrm{C}_{33}\right)$;

${ }^{\mathrm{b}} \mathrm{RI}$, Identification was based on the compound of retention indices with those of published data (NIST);

'Retention Time.

Ashokkumar et al. ${ }^{21}$ characterised essential oil content of four varieties of E. cardamomum capsules, of which 1,8-cineole (28.94\%-34.91\%), sabinene $(11.17 \%-13.50 \%), \alpha$-terpineol $(12.47 \%-14.89 \%)$ and $\alpha$-terpinyl acetate (26.68\%-29.60\%) constituents were detected as major constituents and also reported their use in aroma, food, pharmaceutical and cosmetic domains. Han and Parker ${ }^{22}$ showed the presence of $\alpha$-terpinyl acetate (38.00\%), linalyl acetate, 1,8-cineole/eucalyptol (36.0o\%) in E.cardamomum essential oil and demonstrated anti-inflammatory and immune modulatory potential due to presence of eucalyptol. Iranian E. cardamomum essential oil showed the presence of $\alpha$-terpineol acetate (11.78\%), nerolidol (8.82\%), linalool (10.15\%), $\alpha$-pinene (8.11\%), 1,8-cineole (4.25\%), geranyl acetate (3.47\%), $\gamma$-terpinene (3.88\%), according to Asadollahi-Baboli and Mani-Varnosfaderani ${ }^{23}$. Kaskoos et al. ${ }^{24} \mathrm{char}-$ acterised essential oil of $E$. cardamomum fruits and recorded monoterpenes (87.60\%) of total volatiles such as 1,8-cineole (35.60\%), $\alpha$-terpineol (4.90\%), a-terpinylacetate (27.10\%), thujyl alcohol, linalool (4.10\%) and sesquiterpenes as valencene (1.00\%), t-caryophyllene (0.80\%).

Gradinaru et al. ${ }^{25}$ analysed E. cardamomum fruit essential oil and a-terpinyl acetate (39.59\%), 1,8-cineol (31.27\%) were found as major constituents. Study also revealed that oxygenated monoterpenes (84.54\%) were dominant over monoterpenes (8.27\%) and also investigated combination effect of $E$. cardamomum fruit essential oil with amoxicillin or ciprofloxacin against methicllin-resistant clinical isolates. The volatile oil of seed of $E$. cardamomum was reported to have pinene (2.80\%), sabinene (1.60\%), myrcene (36.00\%), 1,8-cineole, graniol and terpinyl acetate as the major constituents ${ }^{26-27}$. These 
differences in chemical composition could be due to different distillation technique used, climate or growing conditions of plant.

\section{In vitro anti-scabies activity}

The E. cardamomum essential oil was evaluated for their in vitro anti-scabies potential against $S$. scabiei mites. \% Mean mortality for the mites treated with three concentrations of oil is presented in Table 2. E. cardamomum essential oil demonstrated scabicidal potential as its 10\% concentration caused 100\% mortality within $60 \mathrm{~min}$ whereas $5 \%$ diluted solution took 80 min to kill all the mites. Based on \% mean mortalities study, it was found that Permethrin (reference) killed all the mites within 60 min but in negative control group, mortality was only $1.58 \%$ and most of mites remained alive after 80 min of treatment. The scabicidal effects produced by E. cardamomum essential oil were significant ( $\mathrm{p}<0.0001)$ as compared with the respective control groups as demonstrated in Figure 2.

Table 2. In vitro anti-scabies activity of E. cardamomum essential oil against S. scabiei

\begin{tabular}{|c|c|c|c|c|c|}
\hline \multirow{2}{*}{ Test agent } & \multirow{2}{*}{ Conc. } & \multicolumn{4}{|c|}{$\%$ Mortality (mean \pm SEM) } \\
\hline & & $20 \mathrm{~min}$ & $40 \mathrm{~min}$ & $60 \mathrm{~min}$ & $80 \mathrm{~min}$ \\
\hline \multirow{3}{*}{$\begin{array}{l}\text { E. cardamomum } \\
\text { essential oil }\end{array}$} & $1 \%$ & $\begin{array}{l}30.00 \pm \\
0.57^{\star \star \star}\end{array}$ & $\begin{array}{l}42.66 \pm \\
0.56^{\star \star \star}\end{array}$ & $\begin{array}{l}57.33 \pm \\
1.00^{* * *}\end{array}$ & $\begin{array}{l}80.34 \pm \\
0.59^{* * \star}\end{array}$ \\
\hline & $5 \%$ & $\begin{array}{l}39.44 \pm \\
1.53^{* *}\end{array}$ & $\begin{array}{l}48.14 \pm \\
1.15^{\star * *}\end{array}$ & $\begin{array}{l}86.14 \pm \\
0.57^{\star * *}\end{array}$ & $\begin{array}{c}100.00 \pm \\
0.00^{* * *}\end{array}$ \\
\hline & $10 \%$ & $\begin{array}{l}47.81 \pm \\
1.15^{\star \star * *}\end{array}$ & $\begin{array}{l}85.33 \pm \\
0.99^{* * *}\end{array}$ & $\begin{array}{c}100.00 \pm \\
0.00^{* * *}\end{array}$ & $\begin{array}{c}100.00 \pm \pm \\
0.00^{* * *}\end{array}$ \\
\hline \multicolumn{2}{|l|}{ Positive control } & $68.00 \pm 0.20$ & $\begin{array}{c}89.00 \pm \\
0.40\end{array}$ & $\begin{array}{c}100.00 \pm \\
0.00\end{array}$ & $\begin{array}{c}100.00 \pm \\
0.00\end{array}$ \\
\hline \multicolumn{2}{|l|}{ Negative control } & $\begin{array}{c}00.00 \pm \\
0.00\end{array}$ & $\begin{array}{c}00.00 \pm \\
0.00\end{array}$ & $01.58 \pm 0.08$ & $\begin{array}{c}01.58 \pm \\
0.08\end{array}$ \\
\hline
\end{tabular}

Data are expressed as mean $\pm S E M ; n=3$

$* * *, p<0.0001$ indicates highly significant results 


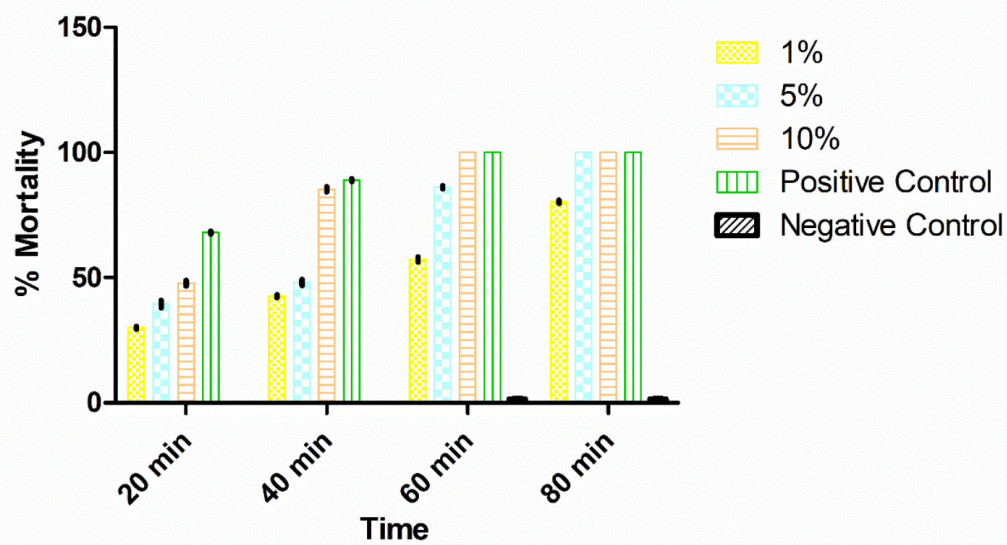

Figure 2. Anti-scabies activity of E. cardamomum leaves essential oil against adult $S$. scabiei. Data are analysed by two-way ANOVA and expressed as mean $\pm S E M, n=3$.

Adupa et al. ${ }^{28}$ reported the toxicant, fumigant and repellent potential of eucalyptol against the maize weevils. Abbassy et al. ${ }^{29}$ study inferred the pronounced insecticidal activity of terpinen-4-ol and $\gamma$-terpinene against tested insects Spodoptera littoralis and Aphis fabae L.

It was also found that eucalyptol enhances the superoxide dismutase and glutathione-s-transferase enzymatic activity, which play a role in protection mechanism of $S$. scabiei mites ${ }^{30}$. The natural components i.e. terpinen-4-ol, $\gamma$-terpinene and eucalyptol have been reported to exhibit insecticidal activity may be responsible for anti-scabies potential of $E$. cardamomum oil. Fang et al. ${ }^{1}$ studied ten essential oils and reported that $1 \%$ clove and palmarosa oil killed all the motile mites within 20 and 50 min, respectively. Using contact bioassay, clove oil (1.56\%) killed all the mites after exposure of 15 min while nutmeg oil showed moderate toxicity against scabies mites ${ }^{31}$. Aboelhadid et al. ${ }^{32}$ stated that $20 \%$ lemon oil caused $100 \%$ mortality of mites after $24 \mathrm{~h}$ and also investigated the elevation in hydrogen peroxide level that leads to considerable cellular damage. Elsholtzia densa also found to possess acaricidal potential against $S$. scabiei and at $16 \mathrm{mg} / \mathrm{mL}$ concentration killed all the mites within 16 $\mathrm{h}$ period ${ }^{33}$.

A number of previous studies have been performed on fruits and seed of $E$. cardamomum. The present study is an attempt made to identify the constituents of volatile oil of $E$. cardamomum leaves and find its utilization for anti-scabies activity. The chemical composition of the leaves is more or less similar to fruits and seeds though the concentrations of the constituents vary. Furthermore, in 
view of its action against $S$. scabiei mites, it may prove to be beneficial to the patients with scabies disease and could be explore as alternative to current medicines.

\section{ACKNOWLEDGEMENTS}

The authors are thankful to Chairperson, Department of Pharmaceutical Sciences, Guru Jambheshwar University of Science and Technology, Hisar for providing necessary facilities to carry out this research work and Dr. Ajay Kumar, AIRF, JNU, Delhi, for his assistance in carrying out GC and GC-MS analysis. The authors also would like to thank Dr. Snahil Gupta, Assistant Professor, Department of Veterinarian Parasitology, Lala Lajpat Rai University of Veterinary and Animal Sciences, Hisar, Haryana for helping us and providing all facilities to carry out anti-scabies activity.

\section{CONFLICT OF INTEREST}

The authors declare no conflict of interest. 


\section{REFERENCES}

1. Fang, F.; Candy, K.; Melloul, E.; Bernigaud, C.; Chai, L.; Darmon, C.; Durand, R.; Botterel, F.; Chosidow, O.; Izri, A.; Huang, W. In vitro activity of ten essential oils against Sarcoptes scabiei. Parasit. Vectors. 2016, 9, 594.

2. Swe, P. M.; Christian, L .D.; Lu, H. C.; Sriprakash, K. S.; Fischer, K. Complement inhibition by Sarcoptes scabiei protects Streptococcus pyogenes-An in vitro study to unravel the molecular mechanisms behind the poorly understood predilection of $S$. pyogenes to infect mite-induced skin lesions. PloS Negl. Trop. Dis. 2017, 11, e0005437.

3. Mejdi, S.; Emira, N.; Ameni, D.; Guido, F.; Mahjoub, A.; Madiha, A.; Abdulbasit, A. Chemical composition and antimicrobial activities of Elettaria cardamomum L. (Manton) essential oil: a high activity against a wide range of food borne and medically important bacteria and fungi. $J$. Chem. Biol. Phy. Sci. Sec. 2015, 6, 248-259.

4. Savan, E. K.; Kucukbay, F. Z. Essential oil composition of Elettaria cardamomum Maton. J. Appl. Biol. Sci.2013, 7, 42-44.

5. Ghosh, S.; Bhattacharjee, P.; Das, S. 1, 8-cineol-rich cardamom seed (Elettaria cardamomum) extracts using green technologies and conventional extractions: Process analysis, phytochemical characterization, and food application. Sep. Sci. Technol. 2015, 5O, 1974-1985.

6. Khatri, P.; Rana, J. S.; Jamdagni, P.; Sindhu, A. Phytochemical screening, GC-MS and FT-IR analysis of methanolic extract leaves of Elettaria cardamomum. Int. J. Res.-Granthaalayah. 2017, 5, 213-224.

7. Goudarzvand, C.S.; Abbasipour, H. Chemical composition and insecticidal effects of the essential oil of cardamom, Elettaria cardamomum on the tomato leaf miner, Tutaabsoluta. Toxin. Rev.2017, 36, 12-17.

8. Agaoglu, S.; Dostbil, N.; Alemdar, S. Antimicrobial effect of seed extract of cardamom (Elettaria cardamomum Maton). YYU Vet. Fak. Derg. 2005, 16, 99-101.

9. Kubo, I.; Himejima, M.; Muroi, H. Antimicrobial activity of flavor components of cardamom Elettaria cardamomum (Zingiberaceae) seed. J. Agric. Food Chem.1991, 39, 1984-1986.

10. Al-zuhair, H.; El-sayeh, B.; Ameen, H. A.; Al-Shoora, H. Pharmacological studies of cardamom oil in animals. J. Pharmacol. Res. 1996, 34.

11. Ghayur, M. N.; Khan, H.; Gilani, A. H. Antispasmodic, bronchodilator and vasodilator activities of (+)-catechin, a naturally occurring flavonoid. Arch. Pharm. Res. 2007, 30, 970-975.

12. Gilani, A. H.; Jabeen, Q.; Khan, A. U. Gut modulatory, blood pressure lowering, diuretic and sedative activities of cardamom. J. Ethnopharmacol. 2008, 115, 463-472.

13. Mersereau, W. A.; Hinchey, E. J. Role of gastric mucosal folds in formation of focal ulcers in rats. Surg.1982, 91, 150-155.

14. Garrick, T.; Buack, S.; Bass, P. Gastric motility is major factor in cold, restraint induced lesion formation in rats. Am. J. Physiol.1986, 250, 6191-6199.

15. Takeuchi, K.; Nishiwaki, K.; Okabe, S. Effect of dopamine on gastric mucosal lesions induced by ethanol in rats - possible involvement of antigastric motor activity mediated with alpha-2adrenoreceptors. Dig. Dis. Sci.1987, 31, 1100-1107.

16. Takeuchi, K. and Nobuhara, Y. Inhibition of gastric motor activity by 16, 16-dimethyl-prostaglandin E2; a probable explanation of cycloprotection. Dig. Dis. Sci. 1985, 3o, 1181-1188.

17. Shay, M.; Komarov, S. A.; Fels, D.; Merenze, D.; Gruenstein, H.; Siplet, H. A simple method for the uniform production of gastric ulceration in rats. Gastroenterology. 1945, 5, 43-63. 
18. Girish, S.A.; Sudhir, G. W.; Avinash, K. D. Evaluation of sedative and anticonvulsant activities of Unmadnashak Ghrita. J. Ethnopharmacol.2004, 94, 77-83.

19. Prabhu, P.; Edayadulla, N.; Anand, S. In vitro antibacterial activity and gas chromatographymass spectrometry analysis of ethanolic extract of leaves of Elettaria cardamomum L. Maton. Asian J. Pharm. Clin. Res. 2019, 12, 73-75

20. Essien, E. P.; Essien, J. P.; Ita, B. N.; Ebong, J.B. Phytochemical properties and fungitoxicity of the essential oil of Citrus medica L. against groundnut storage fungi. Turk J. Bot. 2008, 32, 161-164.

21. Ashokkumar, K.; Murugan, M.; Dhanya, M. K.; Raj, S.; Kamaraj, D. Phytochemical variations among four distinct varieties of Indian cardamom Elettaria cardamomum (L.) Maton. Nat. Prod. Res. 2019, 1-4.

22. Han, X. and Parker, T.L. Cardamom (Elettaria cardamomum) essential oil significantly inhibits vascular cell adhesion molecule 1 and impacts genome-wide gene expression in human dermal fibroblasts. Cogent. Med. 2017, 4, 1308066.

23. Asadollahi-Baboli, M. and Mani-Varnosfaderani, A. Chemometrics-assisted GC-MS analysis of volatile and semi-volatile constituents of Elettaria cardamomum. Food Anal. Methods. 2014, 7, 1745-1754.

24. Kaskoos, R. A.; Ali, M.; Kapoor, R.; Akhtar, M.M.S.; Mir, S.R. Essential oil composition of the fruits of Eletteria cardamomum. J. Essent. Oil Bear Pl. 2013, 9, 81-84.

25. Gradinaru, A.C.; Aprotosoaie, A. C.; Trifan, A.; Spac, A.; Brebu, M.; Miron, A. Interactions between cardamom essential oil and conventional antibiotics against Staphylococcus aureus clinical isolates. Farmacia. 2014, 62, 1214-1222.

26. Korikanthimath, V.S., Ravindra, M., Zachariah, T. J. Variation in yield and quality characters of cardamom clones. J. Med. Aromat. Pl. Sci. 1997, 19, 1024-1027.

27. Lawrence, B.M. Major tropical spices- cardamom (Elettaria cardamomum). In: Hagers Handbuch der pharmazeutischen Praxis (Ed. Franz von Bruchhausen). Allured Publishing Co. Wheaton, Illinois, 1978; pp- 105-155.

28. Adupa, E.; Kagoya, S. Bio-insecticidal activity of eucalyptol and 1R-alpha-pinene rich acetonic oils of Eucalyptus saligna on Sitophilus zeamais Motschulsky, 1855 (Coleoptera: Curculionidae). J. Health Environ Res. 2018, 4, 153-160.

29. Abbassy, M.A.; Abdelgaleil, S.A.; Rabie, R.Y. Insecticidal and synergistic effects of Majorana hortensis essential oil and some of its major constituents. Entomol. Exp. Appl. 2009, 131, 225232.

30. Hu, Z.; Chen, Z.; Yin, Z.; Jia, R.; Song, X.; Li, L.; Zou, Y.; Liang, X.; Li, L.; He, C.; Yin, L.; Lv, C.; Zhao, L.; Su, G.; Ye, G.; Shi, F. In vitro acaricidal activity of 1,8-cineole against Sarcoptes scabiei var. cuniculi and regulating effects on enzyme activity. Parasitol. Res. 2015, 114, 2959-2967.

31. Pasay, C.; Mounsey, K.; Stevenson, G.; Davis, R.; Arlian, L.; Morgan, M.; Vyszenski-Moher, D.; Andrews, K.; MacCarthy, J. Acaricidal activity of eugenol-based compounds against scabies mites. PLoS One. 2010, 5, e12079.

32. Aboelhadid, S. M.; Mahrous, L. N.; Hashem, S. A.; Abdel-Kafy, E. M.; Miller, R. J. In vitro and in vivo effect of Citrus limon essential oil against sarcoptic mange in rabbits. Parasitol. Res. 2016, 115, 3013-3020.

33. Zhou, Y.; Liao, F.; Weng, J.; Mo, Q.; Xu, R.; Zhang, Y.; Ren, Z.; Zhong, Z.; Zuo, Z.; Peng, G.; Deng, J.; Tang, C.; Hu, Y. Composition and acaricidal activity of essential oil from Elsholtzia densa Benth against Sarcoptes scabiei mites in vitro. Vet Med. 2019, 64, 178-183. 